Przegląd Naukowy - Inżynieria i Kształtowanie Środowiska (2017), 26 (1), 136-147

Prz. Nauk. Inż. Kszt. Środ. (2017), 26 (1)

Scientific Review - Engineering and Environmental Sciences (2017), 26 (1), 136-147

Sci. Rev. Eng. Env. Sci. (2017), 26 (1)

http://iks.pn.sggw.pl

DOI 10.22630/PNIKS.2017.26.1.12

\title{
Kamalia PURBANI
}

Environmental Sciences Doctorate Program

Development Planning Department, City of Bandung, West Java, Indonesia

\section{Collaborative planning for city development. A perspective from a city planner}

Key words: collaborative planning, city development, city planner

\section{Introduction}

Collaborative governance has been developed since early 2000. This model could be characterized by collecting multiple stakeholders in a common forum for consensus decision-making, often led by public agencies (Anshell and Gash, 2008). The principle characteristic is that this leads to the outcomes satisfying all parties involved (Gray, 2000). Booher's analysis shows that there are common characteristics such as policy consensus, community visioning, consensus rule-making, and collaborative network structures in collaborative governance (Innes and Booher, 2004).

One of the problems that may hinder the theories of collaboration is that researchers employ different definitions of "collaboration" (Imperial, 2005). Jody Freeman argues that collaborative governance "requires problem-solving, broad participation, provisional solutions, the sharing of regulatory responsibility across the public-private divide and a flexible engaged agency." (Freeman, 1997), while Innes and Booher argue that collaborative governance models must be engaged in "authentic dialogue" with each stakeholder legitimately representing the interests for which they claim to speak, coming to the table with interests, but also with open minds about their positions and a willingness to "seek mutual gain solutions" (Innes and Booher, 2004).

\section{The new paradigm of planning}

The new paradigm of planning is based on interpretive approaches which recognise the diverse ways of living that exist in pluralist societies, while traditional planning focuses on scientific rationalism in a culturally homogeneous community with a public interest 
(Healey, 2006). The theory of structuration and the theory of communicative action show that the mobilization of networks generates the driving forces of social transformation through interaction. Thus, it is concluded that a new paradigm of planning based on interpretive approaches can be interpreted as an interactive process which has the potential to establish relations and discussion that will create new cultural formations through collaboration rather than through the technical processes of design, analysis and management.

However, sometimes discussions may cause cultural domination rather than intercultural communication. To avoid this limitation, participants need to learn how to understand what the problems are, how to respect each other and how to build consensus. This may encourage people to build up new discussions with the capacity to reshape abstract systems in democratic debates (Healey, 2006). In particular, relational webs based on social interaction can modify powerful forces, such as intense constraints, in a multi-cultural world, and change abstract systems and structuring forces.

Several scholars (Innes and Booher, 1999a; Margerum, 2002; Healey, 2003; Maginn, 2007; Lofgren and Agger, 2008) have defined this new paradigm of planning as collaborative planning. It is argued that through collaborative planning based on interpretive approaches, people can build up relational networks and resolve complex conflicts. In particular, the collaborative planning system plays a significant role in dealing with the complexity and diversity of urban governance fields (Healey, 2003).

\section{Collaborative planning}

Collaborative planning is a new paradigm of planning for a complex contemporary society which usually mediates conflicts between parties through consensus-building processes. It encourages people to be engaged in a dialogue in a situation of equal empowerment and shared information, to learn new ideas through mutual understanding, to create innovative outcomes and to build institutional capacity (Innes and Booher, 2004; Healey, 2006). In particular, Maginn (2007) indicates that collaborative planning can provide policymakers with more effective community participation.

With regard to collaborative planning, Healey (2006) mentions that the processes of collaborative planning can be described as a combination of "soft" and "hard infrastructure", which is called "institutional design": "soft infrastructure" includes informal collaborative strategy-making processes, such as social learning, through which stakeholders communicate with each other and build social, intellectual and political capitals; and "hard infrastructure" refers to the design of political, administrative and legal processes, through which people change the power relations in networks.

Discussing collaborative strategy-making as soft infrastructure, Healey (2006) suggests that an ideal strategy-making method should be "inclusionary argumentation", which can be interpreted as a social learning process. Consensus-building through social learning processes is expected to build up trust, establish new relations of power among participants and generate social, intellec- 
tual and political capital. However, the quality of inclusionary argumentation depends upon several factors (Healey, 2006): the availability of initiators who open up places for argumentation and select participants; openness which gives all stakeholders a voice in discussion; facilitators who encourage high quality discussion, preventing some voices from being ignored; mutual interaction to reframe diverse issues; the formalization of any agreement reached; the monitoring of implementation of any agreement; and the maintenance of consensus. Anshell and Gash (2008) state that inclusionary argumentation requires "face-to-face dialogue, trust building and the development of commitment and shared understanding" between stakeholders.

\section{Collaborative process as key elements of collaborative planning}

In a planning approach based communications stressed the importance of cooperation with based communication among stakeholders as shown by a planning approach transactive (Friedman, 1973), collaborative planning (Healey, 1996), planning communicative (Sager, 1994; Innes, 1998), planning deliberative-participatory (Forrester, 2000) and the planning of consensus (Woltjer, 2000). The process that includes activity of dialogue, participation and oriented to the joint decision, summarized in a collaborative process.

Innes and Booher (2000) describe the collaborative process in a Dynamic Network (DYADIC) diagram, in which the diversity and interdependence of the agents are united by an authentic dialogue in which the process will produce exchange, relationships, learning and creativity. The dialogue will eventually produce an adaptation of a system. Network of DYADIC is a very important aspect in collaborative planning, while how the dialogue goes, described by Anshell and Gash (2008) in a cycle in Collaborative Governance Model.

Driving and obstacles factors in collaboration process are also described in Collaborative Governance Model (Anshell and Gash, 2008). The models incorporate the critical factors that determine the process of collaboration, namely: the initial conditions, institutional design, and leadership. The initial condition consists of trust, conflict and social capital into supporting and collaboration. Institutional design compiles rules in the process of collaboration. Leadership provides an important role in mediating and facilitating collaboration. The collaborative process is a cycle that includes: face-to-face dialogue, building trust, commitment to process, shared understanding and intermediate outcomes.

Innes and Booher (2004) consider dialogue, networking and institutional capacity to be a key factor in maximizing the effects of collaborative governance: dialogue encourages participants to share information, understand the perspective of the other partners and creating innovative results; creating networks of mutual trust, encouraging participants to learn the power of collaborative processes; and institutional capacity, which is considered as a combination of social capital, intellectual and political, proliferates through the network and making 
civil society more competent. In addition, Anshell and Gash (2008) suggests that "face-to-face dialogue, build trust and development of commitment and mutual understanding" is an important factor in the collaborative process.

In order to achieve collaboration between actors with the interests and diverse history of the conflict, the dialogue must be genuine, not rhetorical or ritualistic (Isaacs, 1999). Everyone should say what they mean and mean what they say. To be authentic, dialogue must meet several conditions (Habermas, 1981; Fox and Miller, 1996): each speaker must legitimize interests to speak, must speak sincerely, should make a statement that comprehensive for the other and each statement must be accurate. This condition is not obtained directly automatically, but the usual obtained by engaging a facilitator.

Based on Anshell and Gash research (2008) concluded that there are three core contingency factors: (1) time, (2) trust, and (3) where there is interdependence between the interactive effects of trust and interdependence. Interdependence fosters participation and commitment to a more meaningful collaboration, and trust can be built in a situation of interdependence is high.

Johnston et al. (2010) and then follow up studies and prove empirically that if the process of engagement in collaborative governance structure is well managed, then it can be a force in creating the strengthening cycle of trust, commitment, understanding, communication and the result, which is indicator of the success of collaborative government.

\section{The role of stakeholder leadership in collaborative planning}

There has been a growing attention on the discussion of leadership in the planning literature (Balducci and Calvaresi, 2004; Crosby and Bryson, 2005). The relationship between leadership and collaborative planning is not clearly theorized yet, although this is implicitly conceptualized as the "network power", in which power is being shared and confronted with each other (cf. Booher and Innes, 2002; Healey, 2006; Innes and Booher, 2010). Leadership can actually be considered to be an integral part of communicative planning (cf. Crosby and Bryson, 2005). There is an argue that leadership can foster an effective collaboration and consensus building process. Previous studies also show that leadership appears to be one of the key success factors in regional governance (Firman, 2010; Hudalah et al., 2013). An effective leadership framework, which is tailored for specific governance setting, can help mobilize resources, foster dialogues, encourage participation and overcome conflicts between stakeholders (Crosby and Bryson, 2005; Hemphill et al., 2006; Rondinelli, 2009; Talvitie, 2012).

To validate the argument, Fahmi et al. (2016) examine the best practice in urban management Indonesia as evidenced in a street vendor relocation in Surakarta. This case provides an interesting international insight and especially for the nations that have experienced decentralization and restructuration of planning system, such as Indonesia. Besides, the problem of street vendors 
reflects a global phenomenon, which is hardly managed not only in Indonesian cities, but also in many other developing countries (cf. Bhowmik, 2010; Meneses Reyes and Caballero-Juarez, 2014). Street vendors, or pedagang kaki lima (PKL), are very small retails who usually do not have legal permits but that occupy public spaces such as streets, parking areas, stations and parks (Porter et al., 2011). Street vendors in Indonesia reflect the people's reaction to the 1998 monetary crises, which enforced them to search for alternative ways to earn a living. In many cities, street vendor relocation almost always "ends with clashes between officers and the vendors" (BBC Indonesia, 2011).

This case has also been studied through various perspectives concluding that the relocation was carefully designed and communicated beforehand between the local government, street vendors, and other supporting actors, so that these actors collaboratively implemented this project (Porter et al., 2011; Bunnell et al., 2013; Sufianti et al., 2013 Sufianti, 2014; Phelps et al., 2014). Nevertheless, the success appears to be complicated as it "departs from a story linked inextricably with Jokowi's leadership" (Phelps et al., 2014), or Mayor Joko Widodo, who used humanist and cultural values in his approach.

Leadership is widely seen as a critical ingredient in bringing parties to the table and forstering them through the rough patches of the collaborative process (Chrislip and Larson 1994; Reilly 1998, 2001; Smith 1998; Huxham and Vangen, 2000; Roussos and Fawcett 2000; Saarikoski 2000; Margerum 2002; Gunton and Day, 2003; Vangen and Huxham 2003a; Laskerand Weiss 2003;
Frame et al., 2004; Heikkila and Gerlak, 2005; Imperial, 2005; Murdock, Wiessner and Sexton, 2005).

Leadership is crucial for setting and maintaining clear ground rules, building trust, facilitating dialogue, and exploring mutual gains. Vangen and Huxham (2003a) argue tha leadership is important to embrace, empower, and involve stakeholders and then mobilize them to move collaboration forward. Chrislip and Larson (1994) describe the collaborative leader as a steward of the process (transforming, servant, or facilitative leadership) whose leadership style is "characterized by its focus on promoting and safeguarding the process (rather than on individual leaders taking decisive action)". Scholars assert that collaborative governance requires specific types of leadership. Ryan (2001), for example, identifies three components of "effective" collaborative leadership: adequate management of the collaborative process, maintaining "technical credibility" and ensuring that the collaborative is empowered to "make credible and convincing decisions that are acceptable to all". Lasker and Weiss (2001) argue that collaborative leaders must have the skills to (1) promote broad and active participation, (2) ensure broad based influence and control, (3) facilitate productive group dynamics, and (4) extend the scope of the process.

Successful collaborations may also use multiple leaders, formally and informally, rather than relying on one leader (Bradford 1998; Lasker and Weiss 2003). Huxham and Vangen (2000) emphasize that effective collaborative leadership is likely to be time, resource, and skill intensive. 
It is interesting to discuss that leadership is also important for empowering and representing weaker stakeholders. Ozawa (1993), for example, describes what he calls "transformative" techniques in which mediation procedures helps to bring about a "balance of power" among stakeholders. This style of facilitative leadership also helps stakeholders to explore possibilities for mutual gain. Lasker and Weiss (2003) argue that facilitative leaders must "give meaningful voice to participants" and encourage participants to listen to each other. They conclude that leaders should stimulate creativity by synthesizing the knowledge of diverse participants so the group can create new ideas and understanding.

Strengthening the leadership role in collaboration is also expressed by Ryan (2001), Innes and Booher (1999b). They emphasize that the major role of leadership in collaboration is to establish, protect and encourage collaboration by providing a long-term vision and facilitating the consensus-building processes in the face of various obstacles such as distrust. Collaborative leadership plays a significant role in setting rules for collaboration, building trust and facilitating dialogue (Anshell and Gash, 2008). Innes and Booher (1999b) introduce a new style of leadership for the contemporary era, a style of leadership that can suggest a long-term vision, encourage public involvement, build trust among stakeholders and develop participatory skills for social learning processes. In self-governing networks, government is no longer the single leader, because civil society has begun to accumulate its own power since the 1980 s, reflecting a practical knowledge built up in the course of everyday life in its locality (UNDP, 1993; Sullivan and Skelcher, 2002).

Based on the above discussion it can be concluded that the most important factor in establishing collaborative leadership is to recognize the necessity for interdependence between stakeholders. If the stakeholders can realize that their principles will be implemented only through cooperation, this will help them recognize their problems, establish effective working arrangements and reach agreement through shared understanding.

\section{The role of city planners in collaborative planning}

In their article, Brand and Gaffikin (2007) disaggregate collaborative planning into four key elements: ontology, epistemology, ideology and methodology. They make a statement regarding ontology, that statutory plans face a greater legal authority than non-statutory plans where the latter, paradoxically, contains more creativity and imaginative outcomes and therefore possibly reflects the public discourse better (Brand and Gaffikin, 2007). While Innes (2006) states that that "a comprehensive plan is a long range physical plan for a city... [and] a statement of policy rather than a program of specific actions, intended to guide city officials in future actions". In this sense, we should approach a comprehensive plan as a non-statutory plan and regard the document with actual physical actions as a statutory plan.

Collaborative planning could be understood as a power paradigm of stakeholders. Healey (2003) approaches power 
as a relation rather than a "thing". The arguments she gives for her statement that a collaborative planning process is not meant to "neutralize" this power but that power is rather derived from the credibility and legitimacy that people grant to certain institutions, are convincing. Equal distribution of information among all stakeholders is also difficult to achieve because certain information is only available to certain institutions which is not meant to distribute to others, of which political sensitive information is an example. However, the more local the collaborative planning process is in regard to land use and spatial development, the more difficult it is to dodge controversy. This could possibly also harm the collaborative planning processes towards statuary and nonstatuary plans.

The Case studies (Kobler, 2010; Sokol, 2012) confirms that the planners can facilitate an informed decision-making process more effectively among the local participants about the context-specific future of their community. One common theme that emerges in many of the interviews was that planners often need to moderate their expectations for a given community based on input from the local participants in a visioning initiative. Planners effectively balance their roles as advocates and facilitators in collaborative processes by engaging in shared learning with the local participants.

Jorian Walls (2015) proposes extension to the role of a collaborative planner not only as a mediator and knowledge exchanger (Brand and Gaffikin, 2007). Collaborative planners should not only guide a shift from competitive interest bargaining to negotiating consensus building, but they should also use their expert knowledge to enforce their convincing power. By doing so, they enable themselves to "decide" or strongly advise others when other participants within the collaborative planning process fail to use their power and thus in decision making. The collaborative planner should try (among others) to maximize the degree of creativity in both statutory - and non-statutary plans, thereby sketching physical actions a clearly as possible.

\section{The shift role of urban planners in collaborative planning in Indonesia}

Strengthening the role of the legislature in the era of democratization and regional autonomy era brings a new nuance in planning in Indonesia. Local parliament becomes more involved in public policy-making as in budgeting, determination of the development program up to the impeachment of the head region. The planners have a role and a new task in this era which are to identify goals, values and interests of the groups of players involved in a more specific and to identify levels of influence and the efforts taken, to acomodate the interests of each group.

When planning is seen as a tool and method in decision-making and public action, it is very reasonable to understand that there is a political dimension in planning. Political dimension in the formulation of public policy is inseparable from the planning process as an act of rational and scientific. Differences in technocratic planning process with democratic planning are very visible and will affect the role planner for each context. 
Forester (1989) provides fifth perspective in explaining the role of information in a plan that is full of political overtones. That role is of a Technician, Incrementalist, The Liberal Advocative, The Structuralist, The Progressive. While Hardiansah (2005) in his thesis on the role of planners in this era of democratization "Planning: A Case Study of Planning Jalan Dago Lembang", concludes that planner roles in the political process include an engineer, bureaucrat, lawyer and politician.

Approach to development planning has begun to shift from central planning toward participatory planning. Theoretically, such shifts would lead to changes in the role of the planner in planning practices, from planners as applied scientists to a planner as a communicator. In participatory planning, planners expected to carry out a role as a facilitator for accommodating aspiration through discussion and ensure that the marginal also got the chance to have their voice heard.

Participatory planning practices need a qualified planner as a facilitator which will function as a communicator who helps establish dialogue involving all participants to make effective planning that meet the needs and solve problems together.

Changes in the role of the planner requires change of ability and behavior of planners which will be resulting ethical participatory planning process. In carrying out their profession in a participatory planning process, planners not only rely on knowledge and analysis techniques, but also on the ability to establish dialogue or communication parties. Planning is the result of joint discussions.
Basically, there have been basic professional ethics that guide the conduct of planners to carry out their profession ethically, in participatory planning.

Professional ethics that guide the behavior of planners in supporting community participation and responsible to the interests of society are often overlooked given that the planners have controlled by the planning approach of a scientific nature. In supporting participatory planning, they are no longer possible to ignore ethics as a city planner. In addition, to gain the trustt of community and build effective communication based on mutual understanding, trust and cooperation, then the natural pragmatic norms should become a handbook for planners.

\section{Conclusions}

Collaborative governance is a governance model that developed over the last two decades which prioritize consensus among diverse stakeholders. In the world of planning there is also a shift paradigm of planning for a complex contemporary society based on Communicative Rationality Theory that called Collaborative Planning. Collaborative planning can provide policy makers with more effective community participation. The collaborative approach relies heavily on the leadership role that should be able to run a variety of roles. The main role to be undertaken is to build trust and facilitate dialogue.

In line with the shift in approach to the planning, the role of urban planners in the development of the city also experienced a shift. City planning is not just about technocratic process but also 
a political process. In the political process, city planners must be able to perform a variety of roles depending on the situation and context which serves as technocrats, bureaucrats, lawyers and politicians.

In any the situation, city planners must still uphold the ethics as a city planner who puts the responsibility to society, to the assignor and their integrity and professionalism.

\section{References}

Anshell, C. and Gash, A. (2008). Collaborative Governance in Theory and Practice. Journal of Public Administration Research and Theory, 18, 543-571.

Balducci, A. and Calvaresi, C. (2004). Participation and leadership in planning theory and practices. In: M. Haus, H. Heinelt, M. Stewart (Eds.), Urban Governance and Democracy: Leadership and Community Involvement (pp. 234-252). New York: Routledge.

Beatley, T. (1989). Environmental Ethics and Planning Theory. Journal of Planning Literature, 4(1), 1-32.

BBC Indonesia (2011). Memimpin Solo ala Jokowi. BBC Indonesia, 4 August. Available at: http:/www.bbc.co.uk/indonesia/majalah/2011/08/110804_tokohjokowidodo.shtml.

Bhowmik, S. (Ed.) (2010). Street Vendors in the Global Urban Economy. New Delhi, India: Routledge.

Booher, D.E. and Innes, J.E. (2002). Network power in collaborative planning. Journal of Planning Education and Research, 21(3), 221-236.

Bradford, D.L. and Cohen, A.R. (1998). Power up: Transforming organizations through shared leadership. New York: J. Wiley.

Brand, R. and Gaffikin, F. (2007). Collaborative planning in an uncollaborative world. Planning Theory, 6(3), 282-313.

Bunnell, T., Miller, M.A. and Phelps, N.A. (2013). Urban development in a decentralized Indonesia: Two success stories? Pacific Affairs, 86(4), 857-876.
Chrislip, D.D. and Larson, C.E. (1994). Collaborative leadership. San Francisco: Jossey-Bass.

Crosby, B.C. and Bryson, J.M. (2005). Leadership for the Common Good: Tackling Public Problems in a Shared-Power World.2nd edn. New York: John Wiley \& Sons.

Fahmi, F., Prawira, I., Hudalah, D., and Firman, T. (2016). Leadership and collaborative planning: the case of Surakarta. Indonesia. Planning Theory, 15(3), 294-315.

Firman, T. (2010). Multi local-government under Indonesia's decentralization reform: The case of Kartamantul (The Greater Yogyakarta). Habitat International, 34(4), 400-405.

Forester, J. (1999). The deliberative practitioner: Encouraging participatory planning processes. Cambridge, MA: MIT Press.

Forester, J. (2000). Multicultural planning in deed: lessons from the mediation practice of Shirley Solomon and Larry Sherman. In: M. Burayidi (Ed.), Urban Planning in a Multicultural Society (pp. 147-168). Westport, CT: Praeger.

Fox, C.J. and Miller, H.T. (1996). Postmodern Public Administration: Toward Discourse. Thousand Oaks, CA: Sage Publications.

Frame, T.M., Gunton, T. and Day, J.C. (2004). The role of collaboration in environmental management: an evaluation of land and resource planning in British Columbia. Journal of Environmental Planning and Management, 47(1), 59-82.

Freeman, J. (1997). Collaborative Governance in the Administrative State. UCLA Law Review, $54,1-98$.

Gray, B. (2000). Assessing inter-organizational collaboration: Multiple Conceptions and multiple methods. In: D. Faulkner, M. de Rond (Eds.), Cooperative Strategy: Economic, Business, and Organizational Issues. (pp. 243-260). Oxford: Oxford University Press.

Gunton, T. and Day, D. (2003). The theory and practice of collaborative planning inresource and environmental management. Environments, 31, 5-19.

Habermas, J. (1981). Reason and the Rationalization of Society, Vol. 1, The Theory of Communicative Action (T. McCarthy, Trans.). Boston, MA: Beacon Press. 
Hardiansah, E.C. (2005). Peran Perencana dalam Era Demokratisasi Perencanaan: Kasus Perencanaan Jalan Dago-Lembang. Jurnal Perencanaan Wilayah dan Kota, 16(2), 41-63.

Healey, P. (1996). The communicative turn in planning theory and its implications for spatial strategy formation. Environment and Planning B: Planning and Design, 23(2), 217-234

Healey, P. (2003). Collaborative Planning in Perspective. Planning Theory, 2(2), 101-123.

Healey, P. (2006). Collaborative Planning - Shaping Places in Fragmented Societies. 2nd edn. London: Macmillan.

Heikkila, T. and Gerlak, A.K. (2005). The formation of large-scale collaborative resource management institutions: Clarifying the roles of stakeholders, science, and institutions. Policy Studies Journal, 33(4), 583-612.

Hemphill, L., Mcgreal, S., Berry, J. and Watson, S. (2006). Leadership, power and multisector urban regeneration partnerships. Urban Studies, 43(1), 59-80.

Hudalah, D., Firman, T., and Woltjer, J. (2014). Cultural cooperation, institution building, and metropolitan governance in decentralizing Indonesia. International Journal of Urban and Regional Research, 38(6), 2217-2234.

Huxham, C. (2000). The Challenge of Collaborative Governance. Public Management. International Journal of Research and Theory, 2(3), 337-357.

Huxham, C. and Vangen, S. (2000). Leadership in the shaping and implementation of collaboration agendas: How things happen in a not quite) joined-up world. Academy of Management Journal, 43(6), 1159-1175.

Imperial, M.T. (2005). Using Collaboration as Governance Strategy: Lessons from Six Watershed Management Programs. Administration \& Society, 37(3), 281-320.

Innes, J.E. (1998). Information in Communicative Planning. Journal of the American Planning Association, 64(1), 52-63.

Innes, J.E. and Booher, D.E. (1999a). Consensus Building and Complex Adaptive Systems - A Framework for Evaluating Collaborative Planning. Journal of the American Planning Association, 65(4), 412-423.

Innes, J.E. and Booher, D.E. (1999b). Metropolitan Development as a Complex System:
A New Approach to Sustainability. Economic Development Quarterly, 13(2), 141-156.

Innes, J.E. and Booher, D.E. (2004). Reframing Public Participation: Strategies for the 21st Century. Planning Theory and Practice, 5(4), 419-436.

Innes, J.E., Connick, S., Kaplan, L. and Booher, D.E. (2006). Collaborative governance in the CALFED program: Adaptive policy making for California water. Institute of Urban and Regional Development Working paper 1.

Isaacs, W. (1999). Dialogue and the Art of Thinking Together. London: Crown Business.

Johnston, E. (2010). Managing the Inclusion Process in Collaborative Governance. Journal of Public Administration Resources Theory, 21(4), 699-721.

Kobler, A.M. (2009). Building community capacity: how collaborative planning is changing the culture of governance in Seattle (master thesis). Ames: Iowa State University.

Lasker, R.D. and Weiss, E.S. (2003). Broadening participation in community problem solving: a multidisciplinary model to support collaborative practice and research. Journal of Urban Health, 80(1), 14-47.

Lasker, R.D., Weiss, E.S. and Miller, R. (2001). Partnership synergy: a practical framework for studying and strengthening the collaborative advantage. The Milbank Quarterly, 79(2), 179-205.

Lofgren, K. and Agger, A (2008) Democratic Assessment of Collaborative Planning Processes. Planning Theory, 7(2), 145-164.

Maginn, P. (2007). Towards more effective community participation in urban regeneration: the potential of collaborative planning and applied ethnography. Qualitative Research, 6(4), 25-43.

Margerum, R.D. (2002). Collaborative Planning - Building Consensus and Building a Distinct Model for Practice. Journal of Planning and Education and Research, 21, 237-253.

Meneses-Reyes, R. and Caballero-Juárez, J. (2014). The Right To Work on the Street: Public Space and Constitutional Rights. Planning Theory, 13(4), 370-386. DOI: $10.1177 / 1473095213503967$.

Phelps, N.A., Bunnell, T. and Miller, M.A. (2014). Urban inter-referencing within and beyond a decentralized Indonesia. Cities, 39, 37-49. 
Porter, L., Lombard, M. and Huxley, M. (2011). Informality, the commons and the paradoxes for planning: Concepts and debates for informality and planning self-made cities: Ordinary informality? The reordering of a Romany neighbourhood The Land Formalisation Process and the Peri-Urban Zone of Dar es Salaam, Tanzania street vendors and planning in Indonesian cities informal urbanism in the USA: New challenges for theory and practice engaging with citizenship and urban struggle through an informality lens. Planning Theory \& Practice, 12(1), 115-153

Rondinelli, D.A. (2009). Changing concepts of leadership in a globalizing society. In: D.A. Rondinelli, J.M. Heffron (Eds). Leadership for Development: What Globalization Demands of Leaders Fighting for Change (pp. 27-47). Sterling, VA: Kumarian Press.

Ryan, C.M. (2001). Leadership in collaborative policy-making: An analysis of agency roles in regulatory negotiations. Policy Sciences, 34(3), 221-245.

Sokol, M. (2014). Theorizing Planning Practice: Collaborative Planning for Smart Growth on Long Island, New York (master thesis). New York: Columbia University.

Sufianti, E. (2014). Kepemimpinan dan Perencanaan Kolaboratif pada Masyarakat Non Kolaboratif. Jurnal Perencanaan Wilayah dan Kota, 25(1), 77-95.

Sufianti, E., Sawitri, D. and Pribadi, K.N. (2013). Proses Kolaboratif dalam Perencanaan Berbasis Komunikasi Pada Masyarakat Non Kolaboratif. Mimbar, 29(2), 133-144.

Sullivan, H. and Skelcher, C. (2002). Working across Boundaries: Collaboration in Public Services. Basingstoke: Palgrave Macmillan.

Talvitie, A. (2012). The problem of trust in planning. Planning Theory, 11(3), 257-278.

UNDP (1993). Human Development Report. New York: UNDP.

Vangen, S. and Huxham, C. (2003). Enacting leadership for collaborative advantage: $\mathrm{Di}-$ lemmas of ideology and pragmatism in the activities of partnership managers. British Journal of Management, 14(1), 61-76.

Walls, J.R. (2015). Flood resilient cities - A Jakarta case study.
Woltjer, J. (2000). Consensus Planning: The Relevance of Communicative Planning Theory in Dutch Infrastructure Development. Aldershot: Ashgate.

\section{Summary}

Collaborative planning for city development. A perspective from a city planner. A number of definitions related to collaborative governance have been developed since early 2000 . The common characteristics of collaborative governance are, among others, policy consensus, community visioning, consensus rule-making, and collaborative network structures. Collaborative planning is a new paradigm of planning for a complex contemporary society through which it encourages people to be engaged in a dialogue in a situation of equal empowerment and shared information to learn new ideas through mutual understanding, to create innovative outcomes and to build institutional capacity. This indicates that collaborative planning can provide policy makers with more effective community participation.

Collaborative process is the key of collaborative planning which also emphasizes the significant role of collaborative leadership. The process includes a participatory activity of dialogue oriented to the joint decision and summarized in a collaborative process. The collaborative leadership is crucial for setting and maintaining clear ground rules, building trust, facilitating dialogue, and exploring mutual gains.

Along with the shift of planning paradigm, the role of city planner will also change since the city planning deals with the political process. In the political process, city planners must be able to perform as technocrats, bureaucrats, lawyers and politicians who always uphold their ethics because they are responsible to the society, the assignor for their integrity and professionalism. 
Author's address:

Kamalia Purbani

Universitas Padjadjara

Postgraduate School

Jl. Dipati Ukur 35

Bandung Indonesia 40132

e-mail: k.purbani@hotmail.com 